\title{
The Effect of Intervening Tax Avoidance on Leverage on Firm Value
}

\author{
Melinda Wijaya ${ }^{1}$ \\ Fakultas Ekonomi dan Bisnis \\ Universitas Airlangga, Indonesia
}

\author{
Yustrida Bernawati ${ }^{2}$ \\ Fakultas Ekonomi dan Bisnis \\ Universitas Airlangga, Indonesia
}

Surel : melinda.wijaya-2018@feb.unair.ac.id

\begin{abstract}
This study aims to prove the effect of leverage on firm value empirically using tax avoidance as an intervening variable. This study uses company objects listed on the Indonesia Stock Exchange. The research sample used was 66 manufacturing companies listed on the Indonesia Stock Exchange for 2016-2018, which were selected by purposive sampling method, and the number of sample data was 198 data. The firm value variable is measured by price to book value, which was tested using linear regression using SPSS 23 and path analysis. The test results show that: (1) leverage has a significant effect on tax avoidance. (2) leverage and tax avoidance have a significant effect on firm value. (3) the tax avoidance variable cannot be proven as a variable that mediates leverage and firm value.
\end{abstract}

Keywords: Leverage; Tax Avoidance; Firm Value.

\section{Efek Intervening Tax Avoidance pada Leverage terhadap Nilai Perusahaan}

\section{ABSTRAK}

Penelitian ini bertujuan untuk membuktikan secara empiris pengaruh leverage terhadap nilai perusahaan dengan dengan tax avoidance sebagai variabel intervening. Penelitian ini menggunakan objek perusahaan yang terdaftar di Bursa Efek Indonesia. Sampel penelitian yang digunakan sebanyak 66 perusahaan manufaktur yang terdaftar di Bursa Efek Indonesia periode 2016-2018 yang dipilih dengan metode purposive sampling, dan jumlah data sampel adalah 198 data. Variabel nilai perusahaan diukur dengan price to book value. yang diuji menggunakan regresi linier dengan menggunakan SPSS 23 dan analisis jalur. Hasil pengujian menunjukkan bahwa: (1) leverage berpengaruh signifikan terhadap tax avoidance. (2) leverage dan tax avoidance berpengaruh signifikan terhadap nilai perusahaan. (3) variabel tax avoidance tidak berhasil dibuktikan sebagai variabel yang memediasi leverage dan nilai perusahaan.

Kata Kunci: $\quad$ Leverage; Penghindaran Pajak; Nilai Perusahaan.

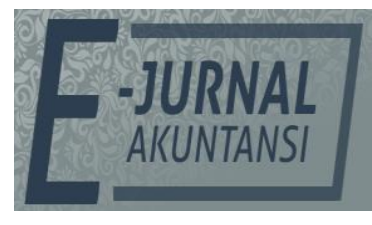

e-ISSN 2302-8556

Vol. 31 No. 1

Denpasar, Januari 2021

Hal. 1-14

DOI:

10.24843/EJA.2021.v31.i01.p01

PENGUTIPAN:

Wijaya, M. \& Bernawati, Y.

(2021). The Effect of

Intervening Tax Avoidance on Leverage on Firm Value. E-Jurnal Akuntansi, 31(1), 1-

RIWAYAT ARTIKEL: Artikel Masuk: 29 September 2020 Artikel Diterima: 15 Desember 2020

Artikel dapat diakses : https://ojs.unud.ac.id/index.php/Akuntansi/index 


\section{INTRODUCTION}

Every company has one goal that will be achieved with a long-term process of maximizing company value. Sartono, (2008) explains that company value as a company's goal is the price that potential investors are willing to pay if a company is to be sold. Investors in making investment decisions in the capital market need information about the value of the company so that the value conditions of public companies must be in good condition.

The value of public companies listed on the IDX cannot be said to be in good overall condition. In theory, according to Sugiarto, (2011) companies that are considered to be running well should ideally have a PBV ratio of greater than one. The phenomenon of the achievement of the value of public companies in the manufacturing category for the last 3 (three) years based on data processed from the IDX is presented briefly in Table 1, illustrating that there are still ups and downs in the achievement of the PBV ratio of public companies in the manufacturing category in Indonesia.

Table 1. Development of the PBV ratio of public companies in the manufacturing category listed on the IDX for the 2016-2018 period

\begin{tabular}{llll}
\hline Industry Classification / Stock Name & \multicolumn{3}{c}{ PBV Ratio } \\
\cline { 2 - 4 } & 2016 & 2017 & 2018 \\
\hline Basic Industry And Chemicals & 1.94 & 1.51 & 1.96 \\
Miscellaneous Industry & 1.23 & 1.23 & 2.55 \\
Consumer Goods Industry & 2.06 & 5.40 & 5.06 \\
\hline
\end{tabular}

Source : www.idx.co.id, 2020

One theory that explains firm value is signaling theory, which states how a company should give signals to users of financial reports (Rehman, 2016) and (Rizqia \& Sumiati, 2013). A signal is an action taken by the management of a company that provides instructions to investors about how management assesses the company's prospects (Brigham \& Houston, 2013). The phenomenon of firm value in the agency theory paradigm, according to Jensen \& Meckling, (1976) describes the agency relationship in agency theory that a company is a collection of contracts (nexus of contract) between owners of economic resources called principals and agents who take care of management and management control of these resources.

Research that has been done to explain the phenomenon of company value with agency theory and signal theory has been carried out, among others (Annisa et al., 2017), (Cheng et al., 2012), (Ilmiani \& Sutrisno, 2014), (Jariah, 2016), (Lestari \& Putri, 2017), (Pradnyana \& Noviari, 2017), and (Yorke et al., 2016). The results of previous research indicate that leverage and tax avoidance are variables that explain the phenomenon of firm value.

Leverage, according to Kasmir, (2014) is a ratio used to measure the extent to which a company's assets are financed with debt. The higher the value of the leverage ratio, the higher the amount of funding from third party debt used by the company, and the higher the interest costs arising from this debt (Welch, 2011). Higher interest costs will have an effect on the high level of tax avoidance. Tax avoidance is an action to reduce or minimize taxation obligations carefully and arrange in such a way as to take advantage of loopholes in taxation 
provisions, such as taxation through transactions that are not taxable (Jacob et al., 2016).

Previous research has shown inconsistent results (gap research) as a background for focused testing and aims to find empirical evidence regarding the effect of leverage on firm value as mediated by tax avoidance. This study is a development of previous studies with the difference that previous studies only examined the impact of leverage on firm value, the impact of leverage on tax avoidance, and the impact of tax avoidance on firm value. In contrast, this study tries to examine the effect of leverage on firm value and to make tax avoidance a mediating variable for the impact of leverage on firm value with the object of research being manufacturing companies listed on the IDX in the 2016-2018 study period.

The main reason for using debt in tax avoidance practices is because the interest due to loans is a tax deduction (Taylor \& Richardson, 2012). The higher the amount of funding from third-party debt used by the company, the higher the costs arising from the debt, which will have the effect of reducing the company's tax burden. The ratio used to measure the extent to which the company's assets are financed with debt is leverage (Kasmir, 2014). The higher the leverage ratio, the higher the debt to third parties, and the higher the interest costs arising from the debt. Research that is still related to leverage conducted by Annisa et al., (2017) found leverage has an effect on tax avoidance. From the explanation above, the hypothesis proposed is as follows.

$\mathrm{H}_{1}$ : Leverage has a significant positive effect on tax avoidance.

A company is insolvable if the company's total debt is greater than the total company-owned (Harjanti et al., 2019). The higher the leverage ratio, the more funds provided by creditors (Kadir, 2016). This will make investors careful to invest in companies with high leverage ratios because high leverage ratios indicate a high investment risk. Increased leverage can provide two kinds of signals, namely good news and bad news Fostel \& Geanakoplos, (2012), Mardiyati, (2012), Suharsono, (2018), and Wulandari \& Wiksuana, (2017). Increased leverage shows bad news if managers make increased leverage out of necessity and not for efficiency reasons. On the contrary, it is good news if the increase reflects a manager's ability to increase value. Research related to leverage conducted by Tarihoran, (2017) proves that leverage has a significant effect on firm value.

Tax avoidance behavior can potentially trigger agency conflicts between the interests of managers and those of investors (Bauer et al., 2018). The company has reasons for practicing tax avoidance, namely, to reduce the tax debt that the company will pay later (Kubick et al., 2016). This is certainly a reflection of the opportunistic behavior of managers who should provide accurate information to investors. The company will report lower profit before tax to obtain a lower tax burden. However, this behavior will undoubtedly reduce the content of the information presented and ultimately will influence investors' decisions in providing value to the company (Chen et al., 2014).

Research related to tax avoidance conducted by Ilmiani \& Sutrisno, (2014) found that tax avoidance behavior has a significant negative effect on firm value, 
which means that the higher the tax avoidance, the lower the firm value. From the explanation above, the hypothesis that can be proposed is as follows.

$\mathrm{H}_{2}$ : Leverage has a significant positive effect on firm value and tax avoidance has a significant negative effect on firm value.

A critical factor in the funding element is debt (leverage), where leverage is the company's ability to pay its debts using its assets (Kasmir, 2014). Leverage has a positive effect on firm value if the company needs funds to keep the company running with debt or perhaps if the company uses debt as additional capital to develop (expansion) the company. Besides, there is an interest expense attached to debt, which will be a tax deduction and have an impact on tax avoidance practices by companies (Lim, 2011). However, tax avoidance practices carried out by management can lead to information bias towards investors, this behavior will certainly reduce the element of investors' assessment of the company (Lanis \& Richardson, 2015).

Research by Jariah, (2016) suggests that leverage partially and simultaneously has a significant effect on firm value, and research from Ilmiani \& Sutrisno, (2014) found that tax avoidance has a significant negative impact on firm value, which means that it is higher The leverage ratio will indicate tax avoidance practices and can affect firm value. From the explanation above, the following hypothesis is proposed.

$\mathrm{H}_{3}$ : Leverage affects firm value positively through tax avoidance as an intervening variable.

Systematically, the research conceptual framework can be seen at Figure 1, is as follows.

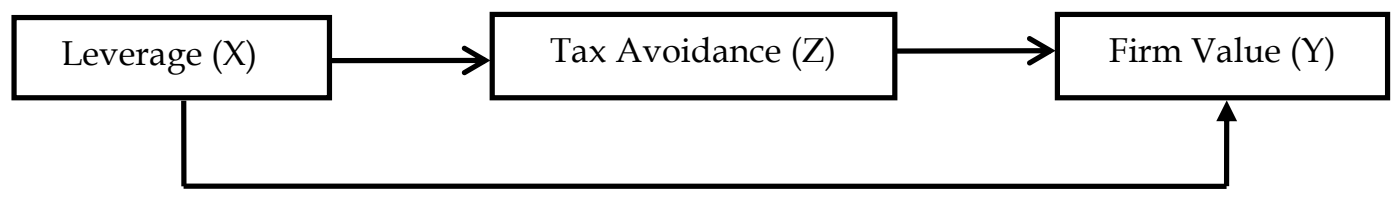

Figure 1. Research Design

Source : Research Data, 2020

\section{RESEARCH METHODS}

This study uses a quantitative method with an archival approach that uses secondary data in the form of company annual reports obtained through the Indonesia Stock Exchange website and the company's official website. The sample of this research is manufacturing companies listed on the Indonesia Stock Exchange in 2016-2018. This study uses panel data with sample selection techniques using purposive sampling. The determination of the sample is done using the purposive sampling method, which is the selection of samples based on certain criteria predetermined. The criteria for determining the sample used in this study were manufacturing companies that did not experience delisting and provided complete data and information on the IDX during the 2016-2018 period; manufacturing companies use the rupiah (Rp) as the reporting currency so that there is no difference due to the changing exchange rates when presented in other currency units; manufacturing companies with positive profit values during the study period. The number of manufacturing companies listed on the 
IDX during 2016-2018 met the criteria to be sampled 66 companies. The observation period used in this study was three years, so that the total sample used was 198 samples. The data collection method used in this study is the documentation method. The documentation method is a method of collecting data by recording and studying documents or archives that are relevant to the problem under study. Documentation of this research is done by downloading and viewing data from annual reports of publicly available companies available on the IDX website and company website. The analytical tool used to test the hypothesis in this study is with testing using IBM SPSS ver 23. The data analysis technique used in this research is regression analysis with path analysis. Path analysis, according to Ridwan \& Kuncoro, (2013), is used to analyze the pattern of relationships between variables to determine the direct or indirect effect of a set of independent (exogenous) variables on the dependent (endogenous) variable. The regression equation in this path analysis uses two structural equations as follows.

$Z=\mathrm{a}+\operatorname{Pzx} X+\mathrm{Pz}_{1}$

$Y=a+P y x X-P y z Z+P y e_{2}$

Note :

$\begin{array}{ll}\mathrm{X} & =\text { leverage } \\ \mathrm{Z} & =\text { tax avoidance } \\ \mathrm{Y} & =\text { firm value } \\ \mathrm{e}_{1} & =\text { error } 1 \\ \mathrm{e}_{2} & =\text { error } 2\end{array}$

\section{RESULT AND DISCUSSION}

The descriptions of the research variables presented in Table 2, provide information about the research variables consisting of the minimum, maximum, mean, and standard deviation.

Table 2. Descriptive Statistics Results

\begin{tabular}{ccccc}
\hline & Minimum & Maximum & Mean & Std. Deviation \\
\hline Leverage & 0.030 & 5.200 & 0.871 & 0.418 \\
Tax Avoidance & 0.005 & 3.360 & 0.307 & 0.296 \\
Firm Value & 0.080 & 62.930 & 3.676 & 2.275 \\
\hline
\end{tabular}

Source : Research Data, 2020

The minimum value for the leverage variable is 0.03 and the maximum value is 5.20 . The average value of the leverage variable is 0.8716 , which indicates that an average of 0.8716 or $87.16 \%$ of the sample companies' equity is financed from debt. Kasmir, (2014) explains that the company's industry average leverage ratio is $80 \%$, so that the average of the sample companies is considered less useful because it is above the industry average. The standard deviation value of the leverage variable is 0.41837 , which means that the range of leverage data values is 0.41837 from the average value. The minimum value for the tax avoidance variable is 0.005 , and the maximum value is 3,360 . The average value of the tax avoidance variable is 0.3079 , which indicates that the average sample company has a tax avoidance rate of 0.3079 or $30.79 \%$. If the CETR calculation result is $<25 \%$, then the company has the status of doing tax avoidance, whereas if the CETR calculation result is $>25 \%$, then the company with the status does not do 
tax evasion so that the average sample company is considered to be tax avoidance because it is above $25 \%$ Astuti \& Aryani, (2016) and Lestari \& Putri, (2017). The standard deviation value of the tax avoidance variable is 0.296605 , meaning that the range of the distribution of tax avoidance data values is 0.296605 from the average value. The minimum value for the firm value variable based on the data in Table 2, is 0.08 , and the maximum value is 62.93 . The average value of the company value is 3.67641 , which indicates that every one company book value is valued by the market at 3.67641. In theory, according to Febriana et al., (2016) and Sugiarto, (2011), companies that are considered to be running well should ideally have a PBV ratio greater than one $(>1)$, which indicates that the stock market value is greater than the company's book value, so the company value category Manufacturers listed on the IDX in 2016-2018 seen from the average have been good. The standard deviation value of the firm value variable is 2.275327, which means that the range of the distribution of the company value data value is 2.275327 from the average value.

Research data requires normality testing to determine whether the residual value of the data is normally distributed or not before it is processed (Ghozali, 2016). This test was performed using the Kolmogorov-Smirnov Nonparametric statistical test. If the value in the Kolmogorov-Smirnov Nonparametric table p-value is more than 0.05 , then the residuals are normally distributed so that it can then be performed multiple regression analysis. The normality test results can be observed in the following Table 3.

Table 3. Normality Test

\begin{tabular}{lcc}
\hline Variable & K-S Z* & 2 tailed p.** \\
\hline The Effect of Intervening Tax & 0.33 & 0.99 \\
Avoidance on Leverage on \\
Firm Value
\end{tabular}

The results of the Kolmogorov Smirnov Test have shown the normal distribution of the model used so that regression can be performed with the Multiple Linear Model.

Table 4. Heteroscedasticity Test

\begin{tabular}{ll}
\hline Variable & t-statistic \\
\hline Leverage & 0.533 \\
Tax Avoidance & 0.386 \\
\hline
\end{tabular}

Source: Research Data, 2020

Dependent Variable $=$ Firm Value

Ttable $\quad=1.972$

Heterokedasticity test aims to determine the variable variance that is not constant in the regression model (Ghozali, 2016). The problem of heteroscedasticity can be tested by looking at the distribution points on the scatterplot graph. If the points on the scatterplot graph spread well and do not form a specific pattern either above or below zero on the $\mathrm{Y}$ axis, then it is concluded that there is no heteroscedasticity problem. Decision making if the 
significance value is higher than $a=5 \%$, then the model does not occur heteroscedasticity. If a data is usually distributed, there is no multicollinearity, and there is no heteroscedasticity problem it can be said that the data is BLUE (Best Linear Unbias Estimation) so that the data can be interpreted further.

From this table, it can be concluded that in the model heterosdasticity did not occur with Tstatistic shown smaller than Ttable.

The multicollinearity test suggests that there is an almost perfect linear correlation between more than two independent variables (Ghozali, 2016). Tests carried out to determine whether there is a high or perfect correlation between independent variables in the regression model that is formed. Multicollinearity testing is done by looking at the value of Variance Inflation Factor (VIF) and Tolerance (TOL). The decision making criteria regarding this test are VIF value less than 10 and TOL more than 0.10 , so there is no multicollinearity, or vice versa if VIF is more than 10 and TOL is less than 0.10 then multicollinearity occurs. In this study, obtained VIF as in the Table 5.

Table 5. Multicollinearity Test

\begin{tabular}{lll}
\hline Variable & VIF value & Note \\
\hline Leverage & 1.035 & $\begin{array}{l}\text { There is no indication of colinearity } \\
\text { between explanatory variables } \\
\text { Tax Avoidance }\end{array}$ \\
1.002 & $\begin{array}{l}\text { There is no indication of colinearity } \\
\text { between explanatory variables }\end{array}$ \\
\hline
\end{tabular}

Source : Research Data, 2020

From this table it can be concluded that for leverage, tax avoidance and firm value do not occur multicollinearity with indicated VIF values smaller than 10. The condition of autocorrelation in the regression model arises when there is a correlation between members of a series of observations arranged according to time sequence (time series data) or according to spatial order (cross-sectional data) or correlation in itself (Ghozali, 2016). The autocorrelation test uses the Durbin Watson Test, which can be seen in Table 6 .

Table 6. Autocorrelation Test

\begin{tabular}{ccccccc}
\hline & $\mathrm{Dl}$ & $\mathrm{du}$ & $4-\mathrm{du}$ & $4-\mathrm{dl}$ & $\mathrm{dw}$ & Interpretation \\
\hline Model 1 & 1.74 & 1.78 & 2.22 & 2.26 & 1.818 & There is no autocorrelation \\
Model 2 & 1.73 & 1.79 & 2.21 & 2.27 & 1.940 & There is no autocorrelation \\
\hline
\end{tabular}

Source : Research Data, 2020

Thus there is no serial correlation between disturbance terms, so the variable is independent (no autocorrelation) which is indicated by $\mathrm{du}<\mathrm{dw}<4-$ du.

Table 7. Stage 1 Regression Analysis

\begin{tabular}{lccc}
\hline \multicolumn{1}{c}{ Variable } & Coefficients & t-statistic & p-values \\
\hline Leverage & 0.030 & 0.671 & 0.000 \\
$\mathrm{R}^{2}$ & & & 0.002 \\
\hline
\end{tabular}

Source: Research Data, 2020

Table 7 , shows the results of stage 1 regression testing. The leverage regression coefficient is 0.030 , which indicates that each addition of one value to the leverage variable will give the tax avoidance variable score an increase of 0.030 . This score shows that leverage has a positive and significant effect on tax avoidance. The value of $\mathrm{R}$ square shows how much the independent variable used in this study can explain the dependent variable used. In this study, the $R$ 
square value is 0.002 , which means that the independent variable can define the dependent variable by $0.2 \%$, while $99.8 \%$ can be explained by other variables outside of this study.

Table 8 , shows the results of regression testing. The value of $R$ square shows how much the independent variable used in this study can explain the dependent variable used. In this study, the $\mathrm{R}$ square value was 0.117 , which means that the independent variable could define the dependent variable by $11.7 \%$, while $88.3 \%$ could be explained by other variables outside of this study. The regression analysis test results show that leverage has a coefficient value of 2.677 with a p-value of 0.000 . This score indicates that leverage has a positive and significant effect on firm value. Tax avoidance has a coefficient value of -2.639 , with a p-value of 0.001 . This score indicates that tax avoidance has a negative and significant effect on firm value.

Table 8. Stage 2 Regression Analysis

\begin{tabular}{lccc}
\hline \multicolumn{1}{c}{ Variable } & Coefficients & t-statistic & p-values \\
\hline Leverage & 2.677 & 3.771 & 0.000 \\
Tax Avoidance & -2.639 & 2.704 & 0.001 \\
$\mathrm{R}^{2}$ & & & 0.117 \\
F statistic & & & 7.791 \\
F significance & & & 0.001 \\
\hline
\end{tabular}

Source : Research Data, 2020

Testing the third hypothesis $\left(\mathrm{H}_{3}\right)$ in this study was tested using path analysis to determine whether the intervening variable sfieceeded in mediating between the independent variable and the dependent variable. The direct effect of $X$ on $Y=2.677$. The indirect effect of $X$ on $Y($ through $Z)=(2.677)(0.030)=$ 0.08031 . Based on these results, the third research hypothesis (H3) is rejected because leverage on firm value is greater than the indirect effect of leverage on firm value through tax avoidance as an intervening variable.

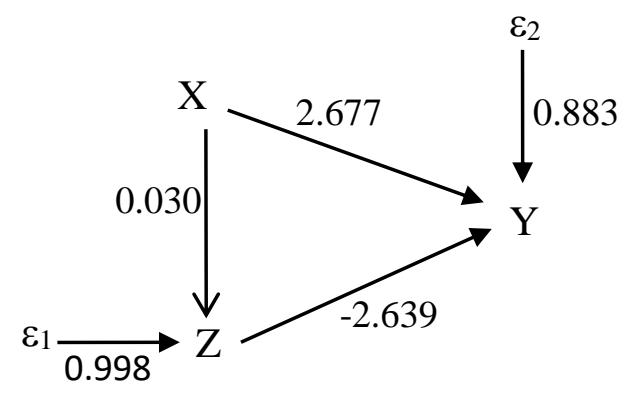

Source: Research Data, 2020

Figure 2. Path Analysis Diagram

The model significance test has been done by comparing the F-table and F-count values. From the test, the F-count is 7.791 with a significance level of 0.001, and the F-table is 3.04. Thus F-count (7.791)> F-table (3.04) means that the regression model is fit and can be further interpreted (Ghozali, 2016). Besides, it is also equipped with a coefficient of determination. The coefficient of determination is a test that can be done to determine the amount of the contribution of the independent variable to the dependent variable (Ghozali, 2016). If the coefficient of determination is high, it shows variations in changes 
that occur in the dependent variable. The assessment of the coefficient of determination can be seen from the R-square value. The coefficient of determination is between zero and one. The R-square value in stage one regression is 0.002 and in regression stage two is 0.117 . If the R-square value gets closer to one, the independent variable provides almost all the information needed to predict the dependent variables. Conversely, the smaller the R-square value, the more limited the ability of the independent variable to explain the variation in the dependent variable (Ghozali, 2016).

The results of testing the first hypothesis state that leverage has a significant effect on tax avoidance because the significant value is smaller than $0.05(0.000>0.05)$. This study has succeeded in proving that the concept of corporate debt, as reflected by the debt to equity ratio (DER) can influence tax avoidance practices in manufacturing sector companies on the Indonesia Stock Exchange in 2016-2018. This study can prove empirically about agency theory in which there is agency conflict in the company, the relationship between principal and agent is manifested in the relationship between shareholders and managers. Managers in running the company have an obligation to manage the company as mandated by shareholders, namely increasing the prosperity of shareholders through increasing company value, in return, the manager will get a high salary, bonus, or compensation. So that in the context of tax avoidance, managers have an interest in manipulating company profits, which will reduce the tax debt borne by the company. Managers can take advantage of debt because a high level of leverage will result in a low tax burden where the interest costs incurred by financing with debt are tax-deductible costs (Heider \& Ljungqvist, 2015), and (Lim, 2011). The higher the value of the leverage ratio, the higher the amount of funding from third party debt used by the company and the higher the interest costs arising from this debt, which will have the effect of reducing the company's tax burden, not making the company financing with as much debt as possible (Buettner et al., 2012), (Egger et al., 2010), and (Kurniasih \& Sari, 2013).

The average leverage of the research sample data on the results of descriptive statistics is $87.16 \%$. This figure is relatively high when compared to the industry average of $80 \%$. Still, it is not accompanied by a level of tax avoidance, which has an average of $30.79 \%$, and can This means that the average company does not avoid taxes when it has high debt. Margaretha \& Ramadhan, (2010) The optimal capital structure occurs when the interest tax shield is balanced with leverage related costs such as financial distress and bankruptcy. To avoid $100 \%$ debt, the cost of debt or financial distress is also considered, which is also called the cost of bankruptcy, which causes the company to not achieve optimal benefits from financing $100 \%$ of the debt. Cost of bankruptcy includes direct costs in the form of legal and administrative expenses of company liquidation, including reorganization costs and indirect costs. Companies also tend to use internal sources of financing, then debt, and finally use equity Ngadiman \& Puspitasari, (2017).

The leverage independent variable has a $\mathrm{t}$-count value that is greater than the $t$-table value $(3.771>1.972)$ and significant value of 0.000 , which is smaller than the value of 0.05 . This shows that leverage is proven to significantly affect firm value in manufacturing sector companies on the Indonesia Stock Exchange 
2016-2018. Increased leverage will have a direct impact on firm value (Chowdhury \& Chowdhury, 2010) and (Tahu \& Susilo, 2017). The acceptance of the second hypothesis indicates that this study has succeeded in proving the concept of leverage as reflected by the Debt to Equity Ratio (DER) that affects firm value in a positive direction in manufacturing sector companies on the Indonesia Stock Exchange 2016-2018. Leverage has an empirical effect on firm value can be explained by signaling theory. Increased leverage can provide two kinds of signals: good news and bad news (Fostel \& Geanakoplos, 2012), (Mardiyati, 2012), (Suharsono, 2018), and (Wulandari \& Wiksuana, 2017). Increased leverage shows bad news if managers make increased leverage out of necessity and not for efficiency reasons. On the contrary, it is good news if the increase reflects a manager's ability to increase value. The positive direction means that the rise in company value is due to the increase in the amount of debt due to the company's management using the debt for business expansion of the company and the company can increase the level of production to obtain greater profits due to the use of debt.

Tax avoidance as an intervening variable has a $t$-count value that is greater than the $t$-table value $(2.704>1.972)$ and a significant value of 0.001 , which is smaller than the value of 0.05 . This shows that tax avoidance is proven to have a significant effect on firm value in manufacturing sector companies on the Indonesia Stock Exchange 2016-2018. The acceptance of the second hypothesis shows that this study has succeeded in proving the concept of tax avoidance or a legal reduction effort carried out by optimally utilizing provisions in the field of taxation, such as exceptions and allowable deductions, as well as taking advantage of things that have not been regulated and weaknesses. Weaknesses in the applicable tax regulations, which are reflected in the Cash ETR (CETR) affecting the value of companies in manufacturing sector companies on the Indonesia Stock Exchange 2016-2018.

Tax avoidance has an empirical effect on the firm value, which can be explained by agency theory, where tax avoidance behavior can potentially trigger agency conflicts between the manager's interests and investors' interests. Companies have reasons for practicing tax avoidance, namely, to reduce the tax debt that the company will pay later. This is undoubtedly a reflection of the opportunistic behavior of managers who should provide accurate information to investors. The company will report lower profit before tax to obtain a lower tax burden. However, this behavior will undoubtedly reduce the content of the information presented, and ultimately will influence investors' decisions in providing value to the company (Chen et al., 2014).

This study has not succeeded in proving the effect of leverage on firm value through tax avoidance as an intervening variable because the indirect effect of 0.08031 is smaller than the direct effect of 2.677. The rejection of the third hypothesis shows that this research has not succeeded in proving the concept of tax avoidance or a legal reduction effort carried out by optimally utilizing provisions in the field of taxation, such as exceptions and allowable deductions, as well as using things that have not been regulated and Weaknesses that exist in the applicable tax regulations, as measured by Cash ETR (CETR), mediate the 
effect of the leverage variable on the variable company value in the manufacturing sector companies on the Indonesia Stock Exchange in 2016-2018.

The results of this study have not been able to prove empirically about agency theory, wherein a company, the relationship between the principal and agent, is manifested in the relationship between shareholders and managers. Managers in running the company should manage the company as mandated by shareholders, namely increasing the prosperity of shareholders through increasing company value. In return, the manager will get a high salary, bonus, or compensation. So that in the context of tax avoidance, management has an interest in manipulating company profits, which will later reduce the tax debt borne by the company. However, manipulating earnings by management causes information bias to investors. This behavior will undoubtedly reduce the element of investors' assessment of the company (Aharoni, 2010) and (Huang et al., 2014).

\section{CONCLUSION}

Based on the research results it can be concluded that the leverage variable has been successfully proven to affect tax avoidance, the leverage and tax avoidance variables have a significant impact on firm value, the leverage variable has not been successfully proven to affect firm value through tax avoidance as an intervening variable. The findings of this study provide practical benefits for investors and potential investors as a reference based on investment considerations and decisions. For the government, the results of this study provide information on how leverage and tax avoidance affect firm value, including in terms of evaluating or updating policies related to tax regulation weaknesses. Public companies are expected to provide benefits as a source of information to assist the company in increasing company value. This article contributes to the development of accounting science in the field of financial accounting theory and the capital market, especially the explanation of the ups and downs of the value of public companies.

This study has limitations, namely the number of samples that are less representative in representing the population because it only uses a sample of manufacturing companies. This research is also only conducted at companies that do not experience losses. This is because companies that make tax payments are the only companies that benefit. Limitations in this study should be further refined, for example, by increasing the sample of companies that include all types of companies listed on the Indonesia Stock Exchange. Besides, it is recommended that future researchers research the same topic in various countries. In the context of taxes, each state has different tax regulations and depends on the policies of each government.

\section{REFERENCES}

Aharoni, Y. (2010). Behavioral elements in foreign direct investments. In The past, present and future of international business \& management. Emerald Group Publishing Limited.

Annisa, A., Taufik, T., \& Hanif, R. A. (2017). Pengaruh Return on Asset, Leverage, Ukuran Perusahaan Dan Koneksi Politik Terhadap Penghindaran Pajak (Studi Empiris Pada Perusahaan Manufaktur Yang Terdaftar Di Bei Periode Tahun 2012- 
2015). Riau University.

Astuti, T. P., \& Aryani, Y. A. (2016). Tren Penghindaran Pajak Perusahaan Manufaktur di Indonesia yang Terdaftar di BEI Tahun 2001-2014. Jurnal Akuntansi, 20(3), 375-388.

Bauer, T., Kourouxous, T., \& Krenn, P. (2018). Taxation and agency conflicts between firm owners and managers: a review. Business Research., 11(1), 3376.

Brigham, E., \& Houston, J. (2013). Dasar-dasar Manajemen Keuangan. Salemba Empat.

Buettner, T., Overesch, M., Schreiber, U., \& Wamser, G. (2012). The impact of thin-capitalization rules on the capital structure of multinational firms. Journal of Public Economics., 96(11-12), 930-938.

Chen, X., Hu, N., Wang, X., \& Tang, X. (2014). Tax avoidance and firm value: evidence from China. Nankai Business Review International.

Cheng, C. A., Huang, H. H., Li, Y., \& Stanfield, J. (2012). The effect of hedge fund activism on corporate tax avoidance. The Accounting Review., 87(5), 14931526.

Chowdhury, A., \& Chowdhury, S. P. (2010). Impact of capital structure on firm's value: Evidence from Bangladesh. Business and Economic Horizons., 3, 3.

Egger, P., Eggert, W., Keuschnigg, C., \& Winner, H. (2010). Corporate taxation, debt financing and foreign-plant ownership. European Economic Review., 54(96-107).

Febriana, E., Djumahir, \& Djawahir, A. H. (2016). Pengaruh Struktur Modal, Kebijakan Deviden, Ukuran Perusahaan, Kepemilikan Saham Manajerial dan Profitabilitas Terhadap Nilai Perusahaan. Jurnal Ekonomi Bisnis, 21(2).

Fostel, A., \& Geanakoplos, J. (2012). Why does bad news increase volatility and decrease leverage?. Journal of Economic Theory., 147(501-525).

Ghozali, I. (2016). Aplikasi Analisis Multivariete Dengan Program IBM SPSS 23. Badan Penerbit Universitas Diponegoro.

Harjanti, W., Farhan, A., \& Radiany, M. A. (2019). The Influence between Debt to Asset Ratio and Debt to Equity Ratio towards the Profit Quality Based on Du Pont Analysis (Case Study of the Companies Listed in the Index of LQ45 in the Year of 2017). Archives of Business Research., 164-170.

Heider, F., \& Ljungqvist, A. (2015). As certain as debt and taxes: Estimating the tax sensitivity of leverage from state tax changes. Journal of Financial Economics., 118(3), 684-712.

Huang, X., Teoh, S. H., \& Zhang, Y. (2014). Tone management. The Accounting Review., 89(3), 1083-1113.

Ilmiani, A., \& Sutrisno, C. R. (2014). Pengaruh Tax Avoidance Variabel, terhadap Nilai Perusahaan dengan Transparansi Perusahaan Sebagai Moderating. Jurnal Ekonomi Dan Bisnis, 14(1), 30-39.

Jacob, M., Rohlfing, B., Anna, \& Sandner, K. W. (2016). Why Do Not All Firms Engage in Tax Avoidance? FAccT Center Working Paper, 19.

Jariah, A. (2016). Likuiditas, Leverage, Profitabilitas Pengaruhnya Terhadap Nilai Perusahaan Manufaktur di Indonesia Melalui Kebijakan Dividen. Riset Akuntansi Dan Keuangan Indonesia, 116.

Jensen, M. C., \& Meckling, W. H. (1976). Theory of the firm: managerial behavior, 
agency costs and ownership structure. Journal of Financial Economics, 3(4), $305-360$.

Kadir, A. (2016). Analisis faktor-faktor yang mempengaruhi kebijakan dividen pada perusahaan Credit Agencies Go Public di Bursa efek Indonesia. Jurnal Manajemen Dan Akuntansi, 11(1).

Kasmir, P. (2014). Analisis Laporan Keuangan. PT. Rajagrafindo.

Kubick, T. R., Lynch, D. P., Mayberry, M. A., \& Omer, T. C. (2016). The effects of regulatory scrutiny on tax avoidance: An examination of SEC comment letters. The Accounting Review., 91(6), 1751-1780.

Kurniasih, T., \& Sari, M. M. (2013). Pengaruh Return on Assets, Leverage, Corporate Governance, Ukuran Perusahaan dan Kompensasi Rugi Fiskal Pada Tax Avoidance. Buletin Studi Ekonomi, 18(1), 61.

Lanis, R., \& Richardson, G. (2015). Is corporate social responsibility performance associated with tax avoidance?. Journal of Business Ethics., 127(2), 439-457.

Lestari, G. A. W., \& Putri, I. A. D. (2017). Pengaruh corporate governance, koneksi politik, dan leverage terhadap penghindaran pajak. E-Jurnal Akuntansi Universitas Udayana, 18(3), 2028-2054.

Lim, Y. (2011). Tax avoidance, cost of debt and shareholder activism: Evidence from Korea. Journal of Banking \& Finance., 35(2), 456-470.

Mardiyati, U. (2012). Pengaruh Kebijakan Dividen, Kebijakan Hutang dan Bursa, Profitabilitas terhadap Nilai Perusahaan Manufaktur yang Terdaftar di Sains, Efek Indonesia (BEI) Periode 2005-2010. Jurnal Riset Manajemen 3(1)., 3(1).

Margaretha, F., \& Ramadhan, A. R. (2010). Faktor-faktor yang mempengaruhi struktur modal pada industri manufaktur di Bursa Efek Indonesia. Jurnal Bisnis Dan Akuntansi, 12(2), 119-130.

Ngadiman, N., \& Puspitasari, C. (2017). Pengaruh Leverage, Kepemilikan Institusional, Dan Ukuran Perusahaan Terhadap Penghindaran Pajak (Tax Avoidance) Pada Perusahaan Sektor Manufaktur Yang Terdaftar Di Bursa Efek Indonesia 2010-2012. Jurnal Akuntansi, 18(3), 408-421. https://doi.org/10.24912/ja.v18i3.273

Pradnyana, I. B. G. P., \& Noviari, N. (2017). Pengaruh perencanaan pajak terhadap nilai perusahaan dengan transparansi perusahaan sebagai variabel moderasi. E-Jurnal Akuntansi Universitas Udayana, 18(2), 1398-1425.

Rehman, O. U. (2016). Impact of capital structure and dividend policy on firm value. Journal of Poverty, Investment and Development., 21(1), 40-57.

Rizqia, D. A., \& Sumiati, S. A. (2013). Effect of managerial ownership, financial leverage, profitability, firm size, and investment opportunity on dividend policy and firm value. Research Journal of Finance and Accounting., 11(4), 120130.

Sartono, A. (2008). Manajemen Keuangan Teori dan Aplikasi Edisi Empat. BPFE.

Sugiarto, A. (2011). Analisa pengaruh beta, size perusahaan, DER dan PBV ratio terhadap return saham. Jurnal Dinamika Akuntansi, 3(1).

Suharsono, R. S. (2018). Pengaruh Mekanisme Good Corporate Governance, Leverage dan Pertumbuhan Total Aset Terhadap Nilai Perusahaan. Jurnal Aplikasi Manajemen Dan Inovasi Bisnis (JAMIN)., 1(1), 25-37.

Tahu, G. P., \& Susilo, D. D. B. (2017). Effect of Liquidity, Leverage and 
profitability to The Firm Value (Dividend Policy as Moderating Variable) in Manufacturing Company of Indonesia Stock Exchange. Research Journal of Finance and Accounting., 18(8), 1697-2222.

Tarihoran, A. (2017). Pengaruh penghindaran pajak dan leverage terhadap nilai perusahaan dengan transparansi perusahaan sebagai variabel moderasi. Jurnal Wira Ekonomi Mikroskil: JWEM, 6(2), 149-164.

Taylor, G., \& Richardson, G. (2012). International corporate tax avoidance practices: Evidence from Australian firms. The International Journal of Accounting., 47(4), 469-496.

Welch, I. (2011). Two common problems in capital structure research: The financial-debt-to-asset ratio and issuing activity versus leverage changes. International Review of Finance., 11(1), 1-17.

Wulandari, N. M. I., \& Wiksuana, I. G. B. (2017). Peranan Corporate Social Responsibility Dalam Memoderasi Pengaruh Profitabilitas, Leverage Dan Ukuran Perusahaan Terhadap Nilai Perusahaan. E-Jurnal Manajemen Universitas Udayana, 6(3).

Yorke, S. M., Amidu, M., \& Agyemin-Boateng, C. (2016). The effects of earnings management and corporate tax avoidance on firm value. International Journal of Management Practice., 9(2), 112-131. 